\title{
CROOKES V. NEWTON: THE SUPREME COURT OF CANADA BRINGS LIBEL LAW INTO THE INTERNET AGE
}

\author{
IRIS FISCHER AND ADAM LAZIER*
}

\section{INTRODUCTION}

After paying little attention to defamation law for decades, in the last few years the Supreme Court of Canada has begun to reshape the field. In what has been described as the "constitutionalization" of defamation law, the Court has recently recognized that the common law was out of step with the right to freedom of expression guaranteed by the Canadian Charter of Rights and Freedoms. ${ }^{1}$ This process began in 2008 with the Court's decision in WIC Radio v. Simpson, ${ }^{2}$ which clarified and expanded the scope of the fair comment defence. The Court went further the following year with Grant v. Torstar Corp, ${ }^{3}$ which recognized an entirely new defence of responsible communication on matters of public interest.

With its recent decision in Crookes v. Newton, ${ }^{4}$ the Court has signalled that the process began by WIC and Grant continues unabated. In fact, the majority decision in Crookes goes further than WIC or Grant in important ways.

For a defendant to be held liable for defamation, that person must have "published" the defamatory statement, which means he or she must have communicated it to someone other than the plaintiff. ${ }^{5}$ Crookes called on the Court to decide whether hyperlinking to defamatory material on a different website constitutes publication of the defamatory material. While three separate sets of reasons were released, all nine judges held in favour of the defendant, and all but Justice Deschamps held that in the circumstances, placing the hyperlink did not constitute publication. In adapting the traditional common law to the Internet context, this decision is a significant vindication of freedom of expression, and the importance of the decision may go well beyond the immediate context of hyperlinking.

To begin with, the decision suggests that English jurisprudence, holding that someone acting as a "mere conduit" has not published defamatory material, may apply in Canada. This has implications for other novel issues concerning libel law in the Internet age. Second, Crookes is the first case in which the Supreme Court of Canada has recognized that freedom of expression is in some contexts best protected by having clear rules that allow people to easily assess their potential liability before making the decision to publish. Finally, the contextual approach to the common law taken by the majority marks a significant departure from how other courts have applied long-established rules to the Internet, and could — if followed in the future — signal a broader move towards a reformulation of libel law in light of technological change.

Iris Fischer and Adam Lazier are lawyers in the Litigation and Dispute Resolution Group of Blake, Cassels \& Graydon LLP's Toronto office, and specialize in media and defamation law.

Part 1 of the Constitution Act, 1982, being Schedule B to the Canada Act 1982 (UK), 1982, c 11.

2008 SCC 40, [2008] 2 SCR 420 [WIC].

2009 SCC 61, [2009] 3 SCR 640 [Grant].

2011 SCC 47, [2011] 3 SCR 269 [Crookes].

McNichol v Grandy, [1931] SCR 696 at 699. 


\section{THE FACTS}

In 2005, the plaintiff, Wayne Crookes, brought a number of lawsuits against authors and Internet intermediaries he alleged were responsible for a “'smear campaign’ against him and other members of the Green Party of Canada." 6 The defendant, Jon Newton, then wrote an Internet article referring to the lawsuits commenced by Crookes. Newton's article included two hyperlinks. One was a "shallow" link, which took the reader to a website containing three articles which Crookes alleged to be defamatory. The second was a "deep” link taking the reader to an article which Crookes alleged to defame him. ${ }^{7}$ Newton did not express an opinion about the allegedly defamatory article or quote it.

Crookes sued Newton for defamation. He did not allege that any of the text on Newton's webpage was itself defamatory. Instead, he argued that Crookes had republished the libellous articles by hyperlinking to them, and that Crookes was therefore liable for the contents of the articles. $^{8}$

Both the British Columbia Supreme Court ${ }^{9}$ and Court of Appeal ${ }^{10}$ (in a two to one decision) found in favour of the defendant. Both courts left open the possibility that a defendant might be found to have published a hyperlinked article where he or she expressed agreement with the contents of that article, even without repeating the defamatory words. However, they found that in merely placing the hyperlinks without expressing such agreement, Newton had not published the allegedly defamatory statements. ${ }^{11}$ In dissenting reasons, Justice Prowse of the Court of Appeal found that Newton had "invited” readers to follow the hyperlinks and had therefore published the libel. ${ }^{12}$

\section{DECISION OF THE SUPREME COURT OF CANADA}

\section{A. MAJORITy Decision}

The majority decision was written by Justice Abella, joined by five other justices. Justice Abella recognized that the traditional publication rule would likely impose liability for hyperlinking in at least some circumstances, as did the minority opinions. Justice Abella noted that " $[\mathrm{t}] \mathrm{o}$ prove the publication element of defamation, a plaintiff must establish that the defendant has, by any act, conveyed defamatory meaning.... Traditionally, the form the defendant's act takes and the manner in which it assists in causing the defamatory content to reach the third party are irrelevant."13 In old English cases, for instance, defendants were found to have published libels by clamping down a printing press, ${ }^{14}$ or merely pointing to a

Crookes, supra note 4 at para 4.

Ibid at paras 6-8. For a discussion of the distinction between shallow and deep hyperlinks, see generally Matthew Collins, The Law of Defamation and the Internet, 3d ed (Oxford: Oxford University Press, 2010) at para 2.43.

Crookes, ibid at para 10.

Crookes v Wikimedia Foundation, 2008 BCSC 1424, [2009] 1 WWR 482 [Crookes (BCSC)].

Crookes v Newton, 2009 BCCA 392, 311 DLR (4th) 647 [Crookes (BCCA)].

Crookes (BCSC), supra note 9 at para 34; Crookes (BCCA), ibid at paras 89-90, Saunders JA (Bauman

JA concurring).

Crookes (BCCA), ibid at para 71.

Crookes, supra note 4 at para 16 [emphasis in original].

$R v$ Clerk (1728), 94 ER 207, cited in Crookes, ibid at paras 18 (per Abella J), 83 (per Deschamps J). 
sign. ${ }^{15}$ Along the same lines, the Privy Council held in 2004 that a New Zealand Member of Parliament republished a previously privileged statement simply by referring to it. ${ }^{16}$ As recently as 1995, the Supreme Court of Canada itself accepted that expressing approval of a statement made by someone else constituted publication. ${ }^{17}$

However, in Crookes Justice Abella held that "reference to an article containing defamatory comment without repetition of the comment itself should not be found to be a republication of such defamatory comment." ${ }^{18}$ In order for a defendant to be liable, he or she actually has to repeat the defamatory content from the linked website. ${ }^{19}$

Justice Abella supported this conclusion in part by analogy to cases dealing with references in other contexts, dating as far back as the $1940 \mathrm{~s} .{ }^{20}$ She also relied, perhaps more persuasively, on policy concerns. She noted that a narrow approach to the publication rule accorded with the modern, "more sophisticated" balance between Charter values and protection of reputation set out in WIC and Grant. ${ }^{21}$ These concerns were particularly acute given the nature of the Internet:

\begin{abstract}
The Internet cannot, in short, provide access to information without hyperlinks. Limiting their usefulness by subjecting them to the traditional publication rule would have the effect of seriously restricting the flow of information and, as a result, freedom of expression. The potential "chill” in how the Internet functions could be devastating, since primary article authors would unlikely want to risk liability for linking to another article over whose changeable content they have no control. Given the core significance of the role of hyperlinking to the Internet, we risk impairing its whole functioning. Strict application of the publication rule in these circumstances would be like trying to fit a square archaic peg into the hexagonal hole of modernity. ${ }^{22}$
\end{abstract}

As Justice Abella pointed out, authors of a web site or online posting usually have no control over the content on the other end of hyperlinks. An innocent link could therefore become defamatory without the author's knowledge. ${ }^{23}$

While Justice Abella's reasons are reasonably clear in setting out a bright-line test for liability for hyperlinking (that is, there is no liability unless the defendant actually repeats the defamatory material), they do include a puzzling statement. When applying the law to the facts of the case, Justice Abella wrote that "the statements containing the impugned hyperlinks on Newton's page could not be understood, even in context with the hyperlinked documents, to express any opinion - defamatory or otherwise - on Crookes or the hyperlinked content." ${ }^{24}$ If Newton must repeat the defamatory material in order to be liable,

Hird v Wood (1894), 38 SJ 234 (CA), cited in Crookes, ibid at para 18

Jennings v Buchanan, [2004] UKPC 36, [2005] 1 AC 115, cited in Crookes, ibid at para 18.

Hill v Church of Scientology of Toronto, [1995] 2 SCR 1130 at para 176 [Hill], cited in Crookes, ibid at para 49, McLachlin CJC and Fish J.

Crookes, ibid at para 24, citing Carter v BC Federation of Foster Parents Assn, 2005 BCCA 398, 42 BCLR (4th) 1 at para 12 [Carter (BCCA)], rev'g Carter v BC Federation of Foster Parents Assn, 2004 BCSC 137, 27 BCLR (4th) 123 [Carter (BCSC)].

Crookes, ibid at para 42.

Ibid at paras 22-24, citing Klein v Biben, 296 NY 638 (Ct App 1946); MacFadden v Anthony, 117 NYS

(2d) 520 (Sup Ct 1952); Carter (BCCA), supra note 16 at para 12.

Crookes, ibid at paras 25, 32-33.

Ibid at para 36 [emphasis added].

Ibid at para 27.

Ibid at para 44 . 
why should we consider his page "in context with the hyperlinked documents"? In addition, why does it matter if Newton expressed an opinion on the hyperlinked content, as long as he did not repeat it?

Justice Abella expressly declined to comment on how these principles might apply to forms of technology not raised in this case, such as hyperlinks that automatically take the user to defamatory content located on a different site. ${ }^{25}$ Unlike the hyperlinks at issue in Crookes, with such automatic links no user intervention is necessary to reach the defamatory content. One commentator has suggested that this is a crucial distinction, and that a court should find a defendant who placed an automatic link to defamatory content to have published that content. ${ }^{26}$ However, this view ignores the policy concerns that justifiably played such an important role in Justice Abella's decision. Automatic links are arguably no less crucial than user-activated links to the operation of the Internet. Limiting their use through increased liability would have the same effect of "seriously restricting the flow of information and, as a result, freedom of expression." 27 In addition, Justice Abella's concerns about holding a defendant responsible for the content of a website over which he or she has no control are just as relevant for automatic links as for user-activated links. It was wise for the Court to leave these difficult issues for a case in which they arise.

\section{B. CONCURRING DECISION OF CHIEF JUSTICE MCLACHLIN AND JUSTICE FiSH}

In brief reasons, Chief Justice McLachlin and Justice Fish adopted a test similar to that employed by the trial court and the Court of Appeal. According to them, "[p]ublication of a defamatory statement via a hyperlink should be found if the text indicates adoption or endorsement of the content of the hyperlinked text." 28 This serves to clarify any confusion arising out of Justice Abella's reasons. Because she evidently disagreed with the Chief Justice and Justice Fish, Justice Abella must have intended not to hold an author liable even if he or she adopts or endorses a defamatory secondary text at the other end of a hyperlink.

The approach of the Chief Justice and Justice Fish may seem compelling at first blush because it appears to strike a compromise between the traditional position and the approach adopted by the majority. On closer inspection, however, it creates more problems than it solves. First, it is not clear what it means to adopt or endorse the content of a secondary website. ${ }^{29}$ The trial judge gave the example of a hyperlink stating "the truth about Wayne Crookes is found here, ${ }^{30}$ but in most cases any endorsement or adoption will be much more

Ibid at para 43. The distinction between automatic and user-operated hyperlinks was explained in $R e$ SOCAN Statement of Royalties, Public Performance of Musical Works 1996, 1997, 1998 (Tariff 22, Internet) (1999), 1 CPR (4th) 417 at 438 (Copyright Board): “A link is automatic when a code is embedded in the Web page which instructs the browser, upon obtaining access to the first site, to automatically download a file from the second site. The information from the second site is pulled without the need for further action on the part of the user. A link is user-activated when the user must click the mouse button over the hyperlink in order to obtain access to the information from the second site."

26 David A Potts, Cyberlibel: Information Warfare in the 21st Century? (Toronto: Irwin Law, 2011) at 260-61.

Crookes, supra note 4 at para 36.

Ibid at para 48 [emphasis in original].

Potts, supra note 26 at 264.

Crookes (BCSC), supra note 9 at para 34 [emphasis in original]. 
subtle. Though the Chief Justice and Justice Fish appear to have had little difficulty concluding that Newton did not adopt or endorse the content of the websites to which he linked, the reality may not be so simple. Why would Newton link to those websites unless he thought they had value and were worthy of his readers' attention?

This approach assumes that a hyperlink itself is neutral, and that adoption or endorsement of a hyperlink is conveyed by the text accompanying that link. This view is incomplete. Users on services like Facebook and Twitter are increasingly communicating by posting links accompanied by little or no commentary. The link itself conveys meaning, and, implicitly, the user's endorsement of that meaning. ${ }^{31}$ Indeed, one key to the success of Google's search engine algorithm is its use of the idea that the relevance and reliability of a website are reflected by how many other websites link to it. ${ }^{32}$

The question of whether Newton had, in fact, adopted or endorsed the defamatory material was difficult enough to split the Court of Appeal. A test predicated on this distinction would create uncertainty from the perspective of individual authors who could not be sure how a court would subsequently interpret their work. ${ }^{33}$ As the Chief Justice herself recognized in Grant, when faced with such uncertainty, the understandable response is often to keep quiet. $^{34}$ The resulting "libel chill” is an affront to freedom of expression. ${ }^{35}$

This approach has another problem. According to the Chief Justice and Justice Fish, adoption or endorsement of the content on the website at the end of a hyperlink "can be understood to actually incorporate the defamatory content into the text." 36 It follows that when the author of website A links approvingly to website B, the author of website A has incorporated into his or her own text not only the text of website $\mathrm{B}$, but also the text of any other websites approvingly linked to by website B (and therefore incorporated into its text), and so on. This makes it effectively impossible for an author to know the full extent of what he or she is being deemed to incorporate. Imposing liability on these terms would be inconsistent with the Court's rejection of strict liability for defamation in Grant, which only underscores Justice Abella's concern that any half-measures risk stifling expression on the Internet.

\section{CONCURRING DECISION OF JUSTICE DESCHAMPS}

Justice Deschamps adopted the most conservative approach, proposing very little change to the traditional publication rule. According to her, a reference to defamatory content in a

Anjali Dalal, "Protecting Hyperlinks and Preserving First Amendment Values on the Internet” (2011) 13:4 U Pa J Const L 1017 at 1019-21.

Ibid at 1021.

Potts appears to advocate an approach under which "approbation [or] adoption" would constitute republication, but "encouragement and invitation" would not: see Potts, supra note 26 at 263 . While this semantic distinction suggests that a higher degree of endorsement on the part of the author would be required, it does not resolve the inherent unpredictabiliy resulting from a court's ex post facto analysis of the statements in question and introduces additional shades of gray into the test suggested by the Chief Justice and Justice Fish.

Grant, supra note 3 at para 53.

Ibid at para 2.

Crookes, supra note 4 at para 51. 
hyperlink or elsewhere will qualify as a publication of the defamatory material where the reference is a deliberate act and makes the defamatory material "readily available." "37

Though Newton's shallow hyperlink did not make the defamatory material "readily available,” Justice Deschamps found that both criteria were met in the case of the deep hyperlink leading directly to one of the articles. On the facts of the case, however, she held that Newton escaped liability because there was no proof anyone had actually followed the link in question.

Justice Deschamps' requirement that the secondary material be made "readily available" is problematic. ${ }^{38}$ It is even less clear and predictable than the "adoption or endorsement" test set out by the Chief Justice and Justice Fish. Justice Deschamps defined "readily available" in vague terms: "[T]here must be no meaningful barrier that would prevent a third party from receiving [the information]." ${ }^{\text {"S }}$ Such a standard would inevitably lead to unpredictable and arbitrary line-drawing. In Crookes, for example, Justice Deschamps concluded that a deep hyperlink, requiring one mouse click on the part of a user, made information readily available. A shallow hyperlink, requiring as few as two mouse clicks, did not.

\section{No PUBLICATION FOR “MERE CONDUITS"}

Justice Deschamps’ reasons are laudable, however, for their embrace of a requirement that "any finding of publication be grounded in a deliberate act." 40 Justice Abella appears to have recognized a similar concept, in that "some acts are so passive that they should not be held to be publication." ${ }^{41}$ Both judges approvingly referenced prior English jurisprudence, which held that intermediaries acting as "mere conduits" are not publishers of defamatory material that they transmit. ${ }^{42}$

In Bunt v. Tilley, ${ }^{43}$ the claimant sought damages from an Internet service provider for allegedly defamatory material posted on a website hosted on its servers. Because the Internet service provider had no knowledge of the allegedly defamatory words, the English High Court held that it had not published them. According to the Court, for a person to be held responsible there must be "knowing involvement in the process of publication of the relevant words." ${ }^{44}$ This was echoed in Metropolitan International Schools Ltd. v. Designtechnica Corp. ${ }^{45}$ In that case, the same Court held that Google was not liable for defamatory

\section{Ibid at para 59 [emphasis in original].}

See Potts, supra note 26 at 261: "The ease or facility of the actions required to be taken by the reader to obtain access to the linked defamatory statement should not dictate whether liability for publication is imposed on the author of the original statement.”

Crookes, supra note 4 at para 94.

Ibid at para 87.

Ibid at para 21.

It is important not to overstate the extent to which the majority adopted this jurisprudence. Justice Abella accepted that some passive acts will not constitute publication, but gave no indication that she adopted the English jurisprudence as a whole. Her acknowledgement of it, however, remains very significant as it is perhaps the first indication of how the Court will deal with these issues as they continue to arise. It is also important that Justice Deschamps approvingly discussed the English jurisprudence in more depth. 
information reprinted in the snippets it automatically generates from search results. The Court recognized that "for a person to be fixed with responsibility for publishing defamatory words, there needs to be present a mental element."46 Once the intermediary is made aware of the defamatory content, however, it may become a publisher of it unless it takes steps to remove it. ${ }^{47}$

Recognizing that publication has such a "mental element" is extremely significant in the context of the Internet, well beyond the issue of liability for hyperlinking. It is particularly relevant to the liability of intermediaries. Intermediaries, like Internet service providers, search engines, and hosts of message boards, are essential to the expression fostered by the Internet. From a practical perspective, it is impossible for many such intermediaries to monitor the content that is posted to their servers, much less to evaluate whether it is defamatory and take steps to remove it if it is. There is no automated way for an intermediary to filter defamatory content. ${ }^{48}$ The process is made even more difficult by the fact that an Internet intermediary must be concerned about different and sometimes conflicting legal regimes in a host of different jurisdictions. ${ }^{49}$ Faced with the spectre of broad liability, intermediaries could either spread the cost among all customers, making Internet access and web hosting more expensive and less accessible, or simply refuse to transmit content that is not from a "trusted" source. ${ }^{50}$ In either case, the Internet's power as an accessible and democratic tool of communication would be significantly weakened. ${ }^{51}$

Until now, courts in Canada have assumed that intermediaries are publishers of defamatory material they transmit. The question has therefore been whether such intermediaries can rely on any defences, such as the innocent dissemination defence that protects those who play a secondary role in the distribution of a libel from liability in the absence of negligence. ${ }^{52}$ In Crookes, however, the Supreme Court suggested that passive involvement in the publication of a libel will not lead to a finding of publication. It follows that an intermediary which does not act deliberately need not even resort to an affirmative defence. ${ }^{53}$ Given the problems that courts in Canada and elsewhere have had in applying the innocent dissemination defence to the Internet and other forms of new technology, this is significant.

Metropolitan, ibid at para 49, cited in Crookes, supra note 4 at para 21, Abella J.

Bunt, supra note 43 at para 25.

Mark A Lemley, “Rationalizing Internet Safe Harbors” (2007) 6 Journal on Telecommunications and High Technology Law 101 at 110; Susan Freiwald, "Comparative Institutional Analysis in Cyberspace: The Case of Intermediary Liability for Defamation” (2001) 14:2 Harv JL \& Tech 569 at 617-18; Ryan Savage, "Between a Rock and a Hard Place: Defamation and Internet Service Providers” (2002) 2 Asper Review of International Business and Trade Law 107 at 117.

Lemley, ibid at 118-19; Scott Sterling, "International Law of Mystery: Holding Internet Service Providers Liable for Defamation and the Needs for a Comprehensive International Solution” (2001) 21 Loy LA Ent LR 327 at 327-28.

Lemley, ibid at 111-12.

Lunney v Prodigy Services, 723 NE (2d) 539 at 542 (NY 1999): “The public would not be well served by compelling an ISP to examine and screen millions of e-mail communications, on pain of liability for defamation."

See Carter (BCCA), supra note 18 at para 21. See also Collins, supra note 7 at para 6.48 (describing this as the "orthodox approach" across the Commonwealth).

This point is made explicitly in Bunt, supra note 43 at para 37: “[P]ersons who truly fulfil no more than the role of a passive medium for communication cannot be characterised as publishers: thus they do not need a defence.” 


\section{A. THE Limits OF THE INNOCENT DisSEMINATION DEFENCE}

The classic case on the innocent dissemination defence is Vizetelly v. Mudie's Select Library Ltd., ${ }^{54}$ which concerned a library that circulated a book containing defamatory material. The defendant did not check the content of books before circulating them and was not aware that the book in question contained a libel. The English Court of Appeal held that, where a defendant plays a subordinate role in the distribution or dissemination of a libel, he will be deemed not to have published it where:

1) the defendant disseminated the libel in the ordinary course of business;

2) the defendant was not aware of the libel (he was “innocent”);

3) nothing in the work or the surrounding circumstances should have led the defendant to suppose that it contained a libel; and

4) the fact that the defendant was not aware of the libel was not the product of negligence on his part. ${ }^{55}$

The Court in Vizetelly found against the defendant, holding that the library was negligent for not having hired enough employees to scrutinize the books it was lending. ${ }^{56}$ Over the years the innocent dissemination defence has also been applied to vendors of books, magazines, and newspapers, newspaper carriers, and printers, as well as libraries. ${ }^{57}$ The defence was recognized by the Supreme Court of Canada in a 2004 decision. ${ }^{58}$ Although the early cases were not clear on this point, it is now generally accepted that innocent dissemination is a defence that can be raised only after it has been proven that the defendant published the defamatory material. ${ }^{59}$

There has been little guidance in Canada on whether and how the innocent dissemination defence will apply to new technology. For instance, at what point might a defendant's decision to rely on technology make him or her negligent? In a 1996 case, an Ontario court held that the defence protected a printer using new technology allowing it to print books without ever seeing their contents. ${ }^{60}$ The printer's decision to adopt this technology was not negligent, even though it meant that the printer could not screen its publications for defamatory content.

[1900] 2 QB 170 (CA) [Vizetelly].

Ibid at 180 .

Ibid at $176-77$.

Raymond E Brown, The Law of Defamation in Canada, 2d ed (Toronto: Carswell, 1999) vol 1 at s 7.12(6)(c).

Society of Composers, Authors and Music Publishers of Canada v Canadian Assn of Internet Providers, 2004 SCC 45, [2004] 2 SCR 427 at para 89.

59 See Thompson v Australian Capital Television Pty Ltd, [1996] HCA 38, 186 CLR 574 at 586 [Thompson]. See also Collins, supra note 7 at para 17.02. There is very little Canadian law on this point, although in one leading case the court appears to have addressed the question of publication separately from the innocent dissemination defence: see Menear v Miguna (1996), 30 OR (3d) 602 at 605 (Gen Div), rev'd on other grounds (1997), 33 OR (3d) 223 (CA) [Menear]. In her concurring opinion in Crookes, supra note 4 at paras 89-91, 113-14, Justice Deschamps also clearly addressed the innocent dissemination defence as a distinct issue arising only after publication is established. 
Until Crookes, the only Canadian case that dealt with the innocent dissemination defence in the Internet context was the British Columbia Court of Appeal's decision in the 2005 case of Carter (BCCA), and it did little to clarify matters. The BC Federation of Foster Parents Association (Federation) was an organization of foster parents that operated a website and message board, but did not exercise any editorial control over the message board. In February 2000, a user posted a defamatory comment on the board. The Federation eventually asked its Internet service provider to shut the board down. Unbeknownst to the Federation, however, the message board was not closed, but was instead converted to a "read-only" state that left previously-posted comments accessible. The Federation did not find out that the message board was still accessible until it was served with the plaintiff's statement of claim at the end of May 2002, more than two years after it had decided to shut the message board down. ${ }^{61}$

In language that presaged Bunt and Crookes, the trial court held that the Federation's passive role meant it was not a publisher of the comments. ${ }^{62}$ The Court of Appeal reversed the trial judge on this point. Rather than examining the Federation's conduct at the publication stage, the Court of Appeal appears to have assumed that the Federation was a publisher. The Court focused instead on whether the Federation was entitled to the innocent dissemination defence. The Court held that the defence did not apply, because the Federation was negligent in not following up to ensure that its instructions were followed. Citing Vizetelly, the Court held that a defendant trying to raise this defence bears a "heavy burden ... to demonstrate that the publication occurred without negligence on his part.”63

\section{B. THE IMPORTANCE OF THE NEW FRAMEWORK}

One commentator has argued that there is little practical distinction between protecting intermediaries at the publication stage and through the innocent dissemination defence. ${ }^{64}$ As Carter illustrates, however, the usefulness of the innocent dissemination defence to potential Internet defendants is limited by the requirement that the defendant demonstrate it did not act negligently. A standard of care that was practical for a library or newsvendor may be entirely impractical in the context of the Internet, given the sheer volume of information handled by Internet intermediaries. While courts may adapt the standard of care to take into account the technological context, the Court of Appeal in Carter applied the negligence rule with little sympathy to intermediaries, indicating that it will be very difficult for a defendant to show that it did not act negligently. ${ }^{65}$

The notion that passive acts should not be held to be publication in the first place, on the other hand, sidesteps these problems by shifting the focus away from whether the conduit acted negligently. ${ }^{66}$ This framework is not problem-free, as it will not always be clear

\footnotetext{
61 Carter (BCCA), supra note 18 at paras 5-6.

Carter (BCSC), supra note 18 at para 104-105.

Carter (BCCA), supra note 18 at para 21.

Collins, supra note 7 at para 6.49.

Carter (BCCA), supra note 18 at para 21, citing Vizetelly, supra note 54 at 180, referring to the "heavy burden lying upon a defendant to demonstrate that the publication occurred without negligence on his part."

$66 \quad$ Bunt, supra note 43 at para 37. See also David Rolph, "Publication, Innocent Dissemination and the
} Internet After Dow Jones \& Co Inc v Gutnick” (2010) 33:2 UNSWLJ 562 at 577-78. 
whether a defendant qualifies as a passive intermediary, ${ }^{67}$ and even a passive intermediary might be required to remove defamatory content when notified of its existence. ${ }^{68}$ Such "notice and take-down" liability has serious implications for freedom of expression, as intermediaries will often take down material regardless of the merits of a complaint in order to avoid potential exposure. ${ }^{69}$ Nonetheless, this framework (however imperfect) prevents courts from engaging in an expansive and normative inquiry into how the defendant should have conducted its affairs. ${ }^{70}$

\section{Adopting a Clear and Predictable Rule}

When faced with difficult issues in recent years, the Supreme Court of Canada has increasingly opted for flexible and contextual tests that leave lower courts a great deal of discretion, but sacrifice predictability. ${ }^{71}$ In some areas, this trade-off may be worthwhile, but it can be problematic in an area like defamation law, where expression may be chilled by uncertainty. A newspaper that thinks it might be held liable by a court down the line may decide to "spike" a story rather than face the risk of losing an expensive court battle.

Until Crookes, the Supreme Court of Canada did not appear sympathetic to arguments that defamation law requires predictable, bright-line legal standards. For instance, the Court has rejected invitations to adopt the American standard that any public figure suing for libel be required to prove that the defendant acted with actual malice. ${ }^{72}$ When the Court finally did constitutionalize defamation law in Grant, it did so by adopting a non-exhaustive sevenfactor analytical framework. While an important step forward, the Grant decision hardly made the law simpler or more predictable. In fact, it is too early to tell exactly how the responsible communication defence introduced by Grant will play out in the lower courts.

Crookes is noteworthy because it represents a rare instance in which a majority of the Court rejected a contextual approach for a clear rule that aims to ensure predictable outcomes. The concurring decisions are examples of the sort of contextual approaches that might have been applied to this issue. As noted above, neither would have led to predictable outcomes. The majority decision, on the other hand, sets out a clear rule that makes it easy for people to know whether they risk liability before publication.

This is particularly welcome in the case of hyperlinking. While the responsible communication defence will likely be of most use to newspapers and other established media organizations that have access to pre-publication legal advice, hyperlinking affects a much broader cross-section of society: essentially anyone who posts content to the Internet. Much

Collins, supra note 7 at para 6.50 .

Bunt, supra note 43 at para 25 , where the Court held that in assessing whether a defendant was a passive intermediary, a court should consider whether the defendant had knowledge of the defamatory content. Lemley, supra note 48 at 113-14. In the copyright context, "the effect of the notice and takedown system has been to encourage Internet intermediaries to take down any and all content copyright owners complain of, no matter how frivolous the complaint" (ibid at 114).

For a discussion of Thompson, supra note 59, as an example of a case where a court's negligence inquiry under the innocent dissemination defence amounted to a broad condemnation of a journalistic practice, see Collins, supra note 7 at para 17.50 .

Daved Muttart, The Empirical Gap in Jurisprudence: A Comprehensive Study of the Supreme Court of Canada (Toronto: University of Toronto Press, 2007) at 139.

See Hill, supra note 17. 
of the power of the Internet as a medium of expression comes from how it has empowered ordinary people like Newton to share thoughts and opinions with others around the world. ${ }^{73}$ Expecting ordinary people to apply the slippery standards set out in the concurring opinions is unrealistic and unfair. Justice Abella's decision appears to represent a recognition that freedom of expression must be protected pragmatically, and that the right loses meaning if it is only exercised by those who can afford lawyers. This is refreshing.

\section{A Flexible Approach to the Common LAw?}

The essence of the majority decision in Crookes was Justice Abella's conclusion that the common law approach to publication had to be reassessed in light of the harms it could cause if applied to the Internet, because "[s]trict application of the publication rule in these circumstances would be like trying to fit a square archaic peg into the hexagonal hole of modernity."74 This reasoning could lead to adaptation in other areas where the Internet threatens to change the nature of defamation law, and when Crookes was released it marked a significant departure from how courts had dealt with similar issues in the past.

However, in the recent decision of Breeden $v$. Black ${ }^{75}$ on the test for jurisdiction in Internet defamation cases, the Court reverted to the traditional approach of the common law. A website can be read all over the world, and a publisher has no control over where a statement is read. With this comes the threat of a lawsuit from many jurisdictions under a plethora of different legal regimes. ${ }^{76}$ Courts in Canada and elsewhere in the Commonwealth have generally not hesitated to assume jurisdiction in libel cases involving foreign defendants. Citing cases dating back to the nineteenth century, courts have simply applied the traditional common law rule that publication occurs whenever and wherever the defamatory statement is read, and they have been unsympathetic to defendants' arguments that this rule must be re-evaluated in light of its impact on freedom of expression in the context of the Internet. ${ }^{77}$

After Crookes, one might have expected the Supreme Court of Canada to reconsider this approach and critically examine whether the traditional jurisdiction rules were appropriate for application to the Internet. However, in its decision in Breeden, released just months after Crookes, the Court appears to have stepped back from the flexible and critical approach to the common law endorsed by the majority in Crookes. Breeden concerned a libel action commenced in Ontario by Conrad Black, the one-time press baron who renounced his Canadian citizenship to accept a British peerage, and was later convicted of fraud and obstruction of justice and incarcerated in the United States. Black complained of statements

Dalal, supra note 31 at 1036.

Crookes, supra note 4 at para 36.

2012 SCC 19, 343 DLR (4th) 629 [Breeden].

This is particularly significant for Americans, who may be deprived of the strong protections provided to defamation defendants under the First Amendment: see e.g. New York Times $v$ Sullivan, 376 US 254 (1964). Under American law, a defendant will not be held liable for defaming a public figure unless he or she acted with "actual malice," that is, recklessly or with knowledge that the statement was false. Canada, England, and Australia have all declined to adopt this approach.

77 See e.g. Dow Jones \& Co v Gutnick, [2002] HCA 56, 210 CLR 575, citing Duke of Brunswick v Harmer (1849), 14 QB 185 and McLean v David Syme \& Co Ltd (1970), 72 SR (NSW) 513. See also Burke v NYP Holdings, 2005 BCSC 1287, 48 BCLR (4th) 363 at para 18, citing Jenner v Sun Oil Co Ltd, [1952] OR 240 (SC). 
in press releases and reports issued by the Board of Directors of Hollinger International, the Chicago-based company he used to control. Most of the defendants resided in the United States. The Court nonetheless held that that an Ontario court had jurisdiction because the statements complained of were posted on the Internet and downloaded in Ontario. Writing for a unanimous court, Justice LeBel dismissed arguments that the traditional rules should be changed to accommodate the nature of the Internet. Rather than dealing with the substance of those arguments, he simply reiterated the traditional common law position:

The issue of the assumption of jurisdiction is easily resolved in this case based on a presumptive connecting factor - the alleged commission of the tort of defamation in Ontario. It is well established in Canadian law that the tort of defamation occurs upon publication of a defamatory statement to a third party. In this case, publication occurred when the impugned statements were read, downloaded and republished in Ontario by three newspapers. It is also well established that every repetition or republication of a defamatory statement constitutes a new publication. ${ }^{78}$

Questions about how the traditional rules of defamation should be applied in the context of the Internet will likely continue to arise, and Crookes and Breeden appear to represent two distinct approaches. Though Breeden and other jurisdiction cases have only purported to be applying established rules, their suggestion that the common law requires no more than applying old rules to new situations is myopic. These courts ignored the fact that applying established rules in the context of the Internet has new and different implications for freedom of expression. A rule that might strike a fair balance between freedom of expression and protection of reputation for print newspapers may not do so in the context of the Internet, where the potential scope of liability is much greater. In Crookes, Justice Abella could have followed the approach of the jurisdiction cases and simply applied the traditional test for publication at common law. Instead, she recognized that the common law rules had arisen in a very different context, and could not blindly be applied to the Internet. It remains to be seen which approach courts will favour in the future.

\section{CONCLUSION}

This uncertainty aside, the significance of Crookes should not be understated. Though it may be trite to emphasize the profound challenges that the Internet poses for defamation law, Crookes presented the Supreme Court of Canada with its first opportunity to consider these issues in depth. What emerges from Justice Abella's majority decision is a nuanced and pragmatic approach to balancing freedom of expression and the protection of reputation.

Justice Abella recognized that it is impossible to strike the appropriate balance between these values without addressing the technological context. In Crookes, that meant considering the importance of hyperlinking to expression on the Internet, and the harm that could follow from exposing authors to liability for content on a website controlled by someone else. The clear and predictable rule adopted by Justice Abella, and the language in her decision and that of Justice Deschamps, suggesting that intermediaries are not liable as publishers, go a long way towards ensuring that the threat of being sued for defamation does not unduly weaken the Internet's power as a democratic and accessible tool of expression. 
Crookes is likely only a first step in assessing how the law of defamation must change as the Internet and other technological changes revolutionize how information is created and shared. While Breeden is a step in the wrong direction, Justice Abella's decision in Crookes is a hopeful sign that our courts intend to keep up. 